\title{
ÇOK ULUSLU ŞİRKETLERDE HALKLA İLISŞKIILER UYGULAMALARI
}

\section{Öğr.Gör.Dr. Sibel HOŞTUT*}

\begin{abstract}
ÖZ
Uluslararası halkla ilişkiler alanında iki temel yaklaşımın mücadelesi söz konusudur. Bunlar, dünya genelinde tek bir programın ve evrensel halkla ilişkiler ilkelerinin uygulandiğı küresel halkla ilişkiler ile ülkelerin sosyal, siyasal ve kültürel özellikleri dikkate alınarak uygulanan uluslararası halkla ilişkilerdir. Nitel araştırma geleneği çerçevesinde oluşturulan bu çalışmanın amacı, çok uluslu şirketlerin Türkiye'de bulunan şubelerindeki halkla ilişkiler uygulamalarını bu iki temel yaklaşım çerçevesinde incelemektir. Araştırma bulgularına göre uluslararası arenada uygulanan halkla iliş̧kiler salt küresel halkla ilişkiler yerine küresel ve uluslararası halkla ilişkilerin karmasında yoğunlaşmaktadır. Türkiye'deki halkla ilişkiler uygulayıcısı yerel uygulamaları bölgesel ve küresel prensipler ve stratejilerle bir denge içinde uygulama özgürlügüne sahiptir. Uygulayıcı bunu hem küresel hem de bölgesel düzeydeki halkla ilişkiler uygulayıcılarıyla yakın bir işbirliği ve çok yönlü iletişim çalışmalarını yürüterek gerçekleştirmektedir.
\end{abstract}

Anahtar Kelimeler: Çok Uluslu Şirketler, Küresel Halkla İlişkiler, Uluslararası Halkla İlişkiler.

JEL Sinıflandırması: F23, D83, L14

\section{PUBLIC RELATIONS PRACTICES IN MULTINATIONAL CORPORATIONS}

\begin{abstract}
The field of international public relations is dominated by the contest of two main approaches. These are global public relations where a single program and universal principles of public relations are implemented worldwide and, international public relations where each country's social, political and cultural aspects are taken into account. Within the qualitative research tradition, the aim of this investigation is to highlight the global and local public relations practices in subsidiaries of multinatinal corporations located in Turkey. According to the research findings the implementation of public relations in the international arena focuses on the mix of global and international public relations instead of a mere global public relation orientation. Practitioners in Turkey have the freedom of employing local practices in order to balance them with regional and global principles and strategies. They work in close collaboration with practitioners by using multifaceted communication both at the global and regional level.
\end{abstract}

Keywords: Multinational Corporations, Global Public Relations, International Public Relations.

JEL Classification: F23, D83, L14

\footnotetext{
${ }^{*}$ Akdeniz Üniversitesi İletişim Fakültesi, Halkla İlişkiler ve Tanıtım Bölümü, shostut@akdeniz.edu.tr
} 


\section{GİRIŞ̧}

Dünyanın "küresel bir köye" dönüşmesi, yeryüzünde yaşayan hemen herkesi etkilediği gibi, halkla ilişkiler endüstrisini ve halkla ilişkiler uygulamalarını da etkilemiştir (Wakefield, 2011: 1). Bugün çok uluslu şirketlerin halkla ilişkiler ya da kurumsal iletişim departmanlarında çalışan halkla ilişkiler uygulayıcıları farklı kamularla ve farklı kültürlerle ilişki kurmakta ve yönetmektedir. (Sriramesh, Kim ve Tabasaki, 1999: 271). Bu durumda halkla ilişkiler uygulayıcıları tek bir programı farklı pazarlarda mı uygulamalı, yoksa her bir pazar için yerel özelliklerin dikkate alındığı yeni programlar mı yaratmalıdır? Anderson, (1989: 413 aktaran Grunig vd., 1995: 165) dünyanın her yerinde aynı şekilde uygulanan halkla ilişkiler ile her kültür için özelleştirilmiş halkla ilişkiler arasındaki farkı ayırt etmek için küresel ve uluslararası kavramlarını kullanmıştır. Yazara göre uluslararası halkla ilişkiler uygulayıcısı çoklu pazarlarda coğrafi pazara ve kültüre uygun farklı programlar uygularken, küresel halkla ilişkiler uygulayıcısı iki veya daha fazla sayıda ulusal pazarda tek bir programı genel bir perspektiften uygulamaktadır. Yapılan çalışmanın amacı, çok uluslu şirketlerin Türkiye yerelindeki halkla ilişkiler uygulamalarının niteliğini ortaya koymaktır. Bunun için otomotiv sektöründe faaliyette bulunan çok uluslu şirketlerin yönetim biçimleri, şirketlerin yerel düzeydeki halkla ilişkiler departmanları, halkla ilişkiler uygulamaları, halkla ilişkiler uygulayıcıları, uygulayıcıların merkez şirketle ve uluslararası arenada diğer halkla ilişkiler uygulayıcılarıyla kurdukları iletişim irdelenmiştir. Şirketlerin sektörlere göre farkl1lık gösteren yerelleşme ve küreselleşme gereksinimleri, elde edilen bulguların genellenebilir nitelik taşımasına engeldir. Çalışma, otomotiv sektöründe faaliyette bulunan çok uluslu şirketlerin halkla ilişkiler uygulayıcılarının, departmanlarının ve uygulamalarının sorgulanmasıyla sınırlıdır. Sektörle ilgili bu sınırlılık, bundan sonraki çalışmalarda farklı sektörlerdeki şirketlerin halkla ilişkiler uygulamalarının araştırılmasını gerekli kılmaktadır. Böylece şirketlerin sektörel özelliklerine göre şekil alan küresel ve yerel uygulamalar tespit edilerek çok uluslu şirketlerdeki halkla ilişkiler uygulamalarına ve literatürüne katkı sağlanacaktır.

\section{2. ÇOK ULUSLU ŞİRKETLERİN YÖNETIM BİÇIMLERİ}

Çok uluslư şirketleri uluslararası pazarlara açılmaya yönelten sosyal, siyasal, ekonomik, teknolojik nedenli çeşitli itici ve çekici güçler vardır. Burada uluslararası pazarın mevcut pazardan daha çekici olması, ithalata yüksek gümrük tarifeleri uygulaması veya çeşitli sınırlamalar getirmesi, ekonomi, hukuki yap1, ucuz işgücü, doğal kaynaklar ve hammadde gibi nedenler çekici faktörler olarak görülürken, iç piyasa koşullarının yetersizliği, iç pazarın doymuş/durgun olması, ücretlerin yüksek, diğer sosyal hakların gelişmiş olması, vergi mevzuatı, vergi yükünden kaçmak, dış ticaret

† Yabancı literatürde ulus aşırı faaliyetleri tanımlamak için giderek artan bir şekilde ulus ötesi şirket adlandırması (UNCTAD, 2009; Bartlett und Ghoshal 1989) tercih edilirken, Türkçe kaynaklarda yoğun olarak çok uluslu şirket kavramı kullanılmaktadır. Bu nedenle yapılan çalışmada uluslararası arenada yürütülen ticari faaliyetlerin tanımlanmasında çok uluslu şirket adlandırılması kullanılmıştır. 
politikası, ülke dışından talep gelmesi, büyüme isteği gibi mevcut pazarda algılanan zorluklar itici faktörler olarak görülmektedir (Ulaş, 2009: 11-12). Çok uluslu şirketlerin stratejilerini biçimlendiren ve koşullandıran şey, cazip pazarlara hizmet sunma ve cazip kaynak havuzlarına ulaşma arzusu ve ihtiyacıdır. Ayrıca geçmişte devletin finanse ettiği sübvansiyonlar - şu ya da bu yere yatırım yapma karşılığında vergi kolaylıklarının sağlanması - bir karar alma ölçütü olarak giderek önemsizleşmektedir. Örneğin Çin ya da Hindistan'a yatırım yapan batılı firmalar, bunu ev sahibi hükümetin sunduğu önerilerinden dolayı değil, kendi gelecekleri buralarda yattığı için yapmaktadırlar (Ohmae, 2006: 270).

Genelde merkez yönetimin temel tutum ve yönelimleri yabancı ülkedeki uygulamaların yol haritasını belirlemektedir. Heenan ve Perlmutter'e (1979: 15) göre şirketlerin uygulamaları, stratejileri ve politikaları etnosentrik, polisentrik, regiosentrik ve geosentrik organizasyon yapılarına göre farklılık göstermektedir. Çok uluslu bir şirketin belirlemiş ve benimsemiş olduğu yönetim biçimi; şirketin kimliğini, yönetim ve organizasyon yapısını, karar verme yetkisini, değerlendirme, kontrol, teşvik ve ödüllendirme sistemini, örgütsel iletişimi, strateji ve insan kaynakları politikasını (Heenan ve Perlmutter, 1979: 17-19) halkla ilişkiler ve pazarlama faaliyetleriyle ilgili kararları ve uygulamaları etkilemektedir.

\subsection{Etnosentrik Yönelim}

Genel merkezin bulunduğu ülkeye kâr sağlama misyonunu üstlenen etnosentrik yönelim, genel merkezin bulunduğu ülkeye yönelik bir yönetim şekli olarak bilinmektedir. Stratejik kararlarda ulusal pazarın önceliğine önem veren şirket, şirket kültürünün, değerlerinin ve eğilimlerinin başka ülkelerde bulunan şubeler tarafindan eleştirilmesine izin vermez. Yabancı ülkede bulunan şubeyle ilgili önemli kararların merkez tarafından alınması ve şubelere çok sayıda talimatların verilmesi şubenin hareketlerini nispeten kısttlar (Fourboul, 1999 ve Emrich, 2007: 184). Genel merkezin bulunduğu ülkeye yönelik hazırlanan halkla ilişkiler programı diğer ülkelerdeki uygulayıcılar tarafından herhangi bir değişiklik yapılmadan uygulanmaktadır (Vercic, Grunig ve Grunig, 1996: 33). Burada yerel şubedeki uygulayıcının kendi inisiyatifleri doğrultusunda halkla ilişkiler programları hazırlama ve uygulama yetkisi bulunmamaktadır. Bu yönetim modelinde hizmet sunulan pazarların yapısal olarak iç pazarın özellikleriyle benzerlikler göstermesi önemlidir (Keegan vd., 2002: 18). Çünkü ürün, öncelikle merkez ülkede yaşayan tüketicilerin ihtiyaçlarına göre geliştirildiğinden (Dunning ve Lundan, 2008: 252) merkez ülkedeki başarılı bir ürün veya pazarlama planı uyarlama yapılmadan başka ülke pazarlarına sunulur veya uygulanır. Bilginin, bilgi teknolojisinin transferi ve kontrolün sağlanması için liderlik pozisyonlarına merkezin bulunduğu ülkede yaşamış ve yetiştirilmiş kişiler atanmaktadır (Emrich, 2007: 184). Bu kişiler yabancı şubelere merkez şirketin felsefe, kültür ve stratejisinin aktarılmasında önemli bir rol üstlenirler (Selmer ve Leung, 2002: 350). Ancak liderlik pozisyonlarına merkez ülke vatandaşlarının tercih edilmesinin getirdiği sakıncalar da vardır. Bu kişilerin çoğu merkez 
ülke kültürünü ve dilini bildiklerinden, bulundukları çevreye uyum sağlamada zorluklar yaşayabilmekte ve başarısız olabilmektedirler (Mutlu, 1999: 416).

\subsection{Polisentrik Yönelim}

Polisentrik yönetim modeli (yerel odaklı) etnosentrik yönetim modelinden farklı olarak, yabancı ülkede bulunan şubeye yönelik güçlü bir örgütlenme şeklidir. Bu yaklaşımda gelir, kültür, yasalar ve siyaset gibi pazarlararası farkl1l1klar (Onkvisit ve Shaw, 2004: 12-13) nedeniyle ülkenin kültürüne uygun farklılaştırılmış stratejilerin ele alınmasının gerekliliği vurgulanmaktadır (Berndt vd. 2010: 11). Buradaki varsayıma göre her pazarın eşsiz ve dolayısıyla farklı olması dışarıdan bakan kişinin ilgili pazarı anlamasını zorlaştırmaktadır (Onkvisit ve Shaw, 2004: 13). Burada her yabancı şube adeta yarı bağımsız bir şirket olarak değerlendirildiğinden bu şubelerin belirli düzeyde özerklik ve karar verme yetkileri vardır (Emrich, 2007: 184). Merkez şirketin görevi ise, daha çok mali konuları denetlemektir. Polisentrik yönelimde şubeler, genel olarak pazarla ilgili kararlar verme yetkisine sahip olan yerli yöneticiler tarafindan yönetilmektedir. $\mathrm{Bu}$ yöneticiler bulundukları ülke ile olan bağları nedeniyle pazar, kültür ve yerel tüketiciyle ilgili ayrıntılı bilgilere sahiptir (Keegan vd., 2002: 19). Bu yönelimde halkla ilişkiler uygulamaları yerel kültürün özelliklerini içermeli ve yerele öz stratejiler uygulanmalıdır. Burada uygulayıcının karar alma ve verme yetkisi bulunmaktadır (Vercic, Grunig ve Grunig, 1996: 33).

\subsection{Regiosentrik Yönelim}

Regiosentrik (bölge odaklı) yönetim modelinin temelini, belirli bir coğrafyayı paylaşan ülkelerin bölgesel kuruluşlar çerçevesindeki işbirliği simgelemektedir. Buradaki amaç, pazarları bölgelere ayırarak bölgesel düzeyde pazarlama stratejilerinin ve ürün standardizasyonunun geliştirilmesidir (Emrich, 2007: 184). Bu yönelimi, AB, NAFTA veya MERCOSUR gibi serbest bölgeler, ekonomik veya parasal birlikler teşvik etmektedir. Önemli yönetici pozisyonlarında bölge insanı görevlendirilmektedir (Koparal, 2004: 129). Bu yerel yöneticiler belli bir coğrafi bölge içinde başka bir ülkeye de transfer edilebilirler. Burada regiosentrik yönelim, geosentrik yönelime doğru giden basamağ1 yansıtabilir (Berndt vd., 2010: 13). Regiosentrik yönetim modelinde şirket, kendi stratejik ilgi alanlarını bölgesel şubelerle bir araya getirmeye çalışmaktadır. Böylece merkez ve bölge ofisleri arasında karşılıklı müzakerelerde bulunulmakta, bölgesel entegrasyon avantajlarının dengelenmesi ve ulusal ihtiyaç ve isteklerin karşılanması önem taşımaktadır. Pazarlama stratejileri ve faaliyetleri bölge kapsamındaki ülkeler için standardize edilebilir, ancak bölgelerarası standardizasyon sözkonusu değildir (Dunning ve Lundan, 2008: 252). Polisentrik yönelim modelinde tek bir ülkeye yönelik halkla ilişkiler uygulamaları dikkate alınırken, regiosentrik yönelimde belirli bir coğrafyayı paylaşan ülkeler dikkate alınmaktadır. Buradaki ülkeler benzer özelliklere sahip olduklarından halkla ilişkiler uygulayıcısı bölgesel özelliklere uygun uyglamalar ve stratejilerin uygulanmasını sağlamaktadır. 


\subsection{Geosentrik Yönelim}

Geosentrik yönelim ise tümüyle evrensel bir modeldir. Hedef pazar olarak belirli bir ülke yerine dünya geneline yönelme söz konusudur. Şartlar uygun görüldüğünde kurumsal kaynaklar ulusal sınırlar dikkate alınmaksızın tahsis edilmekte ve doğrudan yatırım yapmakta hiçbir tereddüt görülmemektedir (Onkvisit ve Shaw, 2004: 13). Geosentrik yönelimli bir şirket kendisini belirli bir ülke içinde tanımlamaz. Ohmae'ye (1990) göre şirketlerin ulusal kimlikleri olmamalıdır. Bu nedenle şirket merkez ofisini başka yerlere taşımakta sakınca görmemelidir. Şirket, dünya pazarında konumunu güçlendirmek için pazarı dünya boyutlarında düşünmekte, yine dünya genelinde stratejiler araştırmakta ve standart bir program uygulamaktadır. Personel politikası ve yönetim kadroları ulusal kimlikler dikkate alınmadan, küresel bir yaklaşım doğrultusunda kişilerin yeteneklerine göre uygulanmakta (Emrich, 2007: 185-186) ve küresel düzeyde görevlendirebilmek için bu kişilere eğitim programları sunulmaktadır. Son derece karmaşık bir organizyon yapısına sahip bu şirketlerdeki şubeler son derecede birbirine bağımlıdır. Genel merkezden şubelere ve şubelerarası yoğun bir iletişim ve bilgi akışı söz konusudur (Chakravarthy ve Perlmutter, 1985: 5). Bu yönelimde halkla ilişkiler uygulayıcısı genel merkezin evrensel standartlar doğrultusunda belirlediği programları uygulasa da genel merkez ve şubelerarası yürütülen çoklu iletişim akışlarıyla yerel kültürün özelliklerine yönelik program hazırlama ve uygulama yetkisi bulunmaktadır. Bu da Vercic, Grunig ve Grunig'in (1996: 33) etnosentrik ve polisentrik yaklaşımın karmasından faydalanarak orta yol olarak adlandırdıkları yönelimde konumlanmaktadır.

\section{ULUSLARARASI HALKLA İLIŞKILER}

Uluslararası halkla ilişkiler alanında kuramsal egemenlik konusunda iki temel yaklaşımın mücadelesi söz konusudur. Bunlar küresel halkla ilişkileri savunan ve Mükemmellik Ilkelerine (Principles of Excellence) (Kent ve Taylor, 2011: 67) dayanan birinci yaklaşım ile uluslararası halkla ilişkileri savunan ikinci yaklaşımdır (Anderson1989: 413'denaktaran Grunig vd., 1995: 165). Küresel halkla ilişkilerde, en iyi halkla ilişkiler uygulamalarının yerel düzeyde farklı uygulamalar olmasına rağmen, ulusal sınırların ötesinde jenerik olduğu savunulmaktadır (Brinkerhoff ve Ingle, 1989 ve Anderson, 1989: 413'den aktaran Grunig vd., 1995: 165). Sharpe (1992: 104'ten aktaran Grunig, vd., 1995: 165); Brezilya, Türkiye, Kanada, Hollanda ve Nijerya seyahatleri sonrasinda profesyonellerin çalışma koşullarına bakmaksızın halkla ilişkiler ilkelerinin dünya genelinde benzer olduğu sonucuna vararak, küresel yaklaşımı güçlü birşekilde desteklemiştir.

Grunig vd. (1995) uluslararası halkla ilişkileri “uygulayıcıların birçok ülkede çalışmasına olanak tanıyacak ya da birçok ulusun insanları ile işbirliği içinde çalışmasını sağlayacak geniş bir perspektif' olarak tanımlamakta, Yıldırım Becerikli (2012: 90) de, kültürlerarası düzeyde yürütülen uluslararası halkla ilişkilerin faaliyet alanlarının farklı ulusları ve coğrafyaları kapsadığını ifade etmektedir. Uluslararası halkla ilişkiler anlayışında ülkelerin sosyal, siyasi, kültürel, hukuki, medya ve eğitim sistemleri arasındaki farklılıklardan dolayı yerel kültürün her ülkenin halkla ilişkiler 
uygulamalarını benzersiz bir şekilde etkilediği savunulmaktadır (Holtzhausen, 2011: 144-145). Burada kurumun nerede konumlandığı ve hangi kamularla ilişkiler geliştirdiği uluslararası halkla ilişkiler programının önemli unsurları olarak görülmektedir (Wakefield, 1996: 18 ve 2009: 91). Zaharna (2001: 135 ve 137) uygulayıcının bulunduğu ülkede uygulamaya başlamadan önce o ülkenin her alandaki koşullarını (ulusal dil, medya, eğitim sistemi, siyasi ve ekonomik sistem) bilmesini ve farkında olmasını dile getirerek, uluslararası halkla ilişkiler için farkındalık yaklaşımını vurgulamaktadır. Yazara göre farkındalık yaklaşımının amacı, uluslararası halkla ilişkilerdeki gizli kültürel varsayımların ve beklentilerin açığa çıkartılması, müşteriler ve uygulayıcılar arasındaki ulusal ve kültürel farklılıkların sistematik bir biçimde araştırılmasını sağlamaktır (Zaharna, 2001). Ancak genel merkezin gölgesinde değişik zaman dilimleri, değişik değerler, değişik siyasi, ekonomik ve toplumsal sistemler içerisinde, değişen medya kısıtlamaları ile uluslararası arenadaki kamularla ilişki kurmak, Foster'in (1998 aktaran Wakefield, 2009: 93-94) açıklamasına göre halkla ilişkilerin tüm alanları içerisinde yönetilmesi en güç olanıdır. Çünkü uluslararası arenadaki uygulamalar daha karmaşık, daha öngörülemez ve yerel tabanlı halkla ilişkiler programlarından daha çok risk doğurmaktadır. Holtzhausen'e (2011: 145) göre tüm uygulamaların yerel olması durumu (mükemmel uygulama boyutunu içerse bile) jenerik halkla ilişkiler uygulamasını uygulanamaz kılmaktadır. Yazar, konuyu postmodern bir yaklaşımdan irdelemekte ve küresel halkla ilişkiler ile uluslararası halkla ilişkilerin birbirinden çok farklı uygulamalar olduğunu ifade etmektedir (Holtzhausen, 2011: 146). Nitekim halkla ilişkiler alan yazınında halkla ilişkiler üzerine yapılan tanımlamalarda bir uzlaşı olmadığı gibi, küresel ve uluslararası halkla ilişkiler konusunda da yazarların iki uçta görüş sunmaları yazarlar arası bir görüş birliğinin gelişmesini zorlaştırmaktadır.

Çok uluslu şirketlerde etkili halkla ilişkilere ilişkin bir temel oluşturmaya ilişkin bir teşebbüs Vercic, Grunig ve Grunig (1996: 33) tarafından geliştirilen kuramdır. Yazarların, polisentrik ve etnosentrik yönelimler arasında "orta yol" olarak adlandırdıkları bu kuram, farklı kültürlerde; siyasi, ekonomik ve medya sistemlerinde, kültür, gelişmişlik ve eylemcilik faaliyet düzeylerinde uygulama bulabilecek bir dizi küresel halkla ilişkiler ilkelerinin temelini oluşturmaktadır. Polisentrik kurama göre halkla ilişkiler, uygulandığı kültüre uygun olması için her toplumda farklı olmalıdır. $\mathrm{Bu}$ yaklaşıma göre halkla ilişkiler uygulayıcısı, bulunduğu ülke için uygun olduğuna inandığı programları uygulama özgürlügüne sahiptir. Oysa etnosentrik kuramda tek bir kuramın bütün toplumlar için uygun olduğu savunulmaktadır. Yazarlar, bazı genel halkla ilişkiler ilkelerinin tüm kültürler ve toplumlar için uygun olduğunu ileri sürerek etnosentrik ve polisentrik yaklaşımlar arasında köprü kurulmasını önererek, karma yaklaşımından faydalanılması gerektiğine vurgu yapmışlardır (Vercic, Grunig ve Grunig, 1996: 33).

İlgili alan yazınına göre etnosentrik yönelim küresel halkla ilişkiler ve polisentrik, regiosentrik ile geosentrik yönelimler de uluslararası halkla ilişkiler çerçevesinde anlaşılmaktadır. Bu yönelimler 
doğrultusunda halkla ilişkiler uygulamalarına ilişkin ekonomik bir açıklama yapabilmek için Vercic, Grunig ve Grunig (1996) in tanımlamış oldukları etnosentrik ve politisentrik yönelimler kullanılmıştır.

Tablo 1. Etnosentrik ve Polisentrik Yönelimlere İliş̧kin Halkla İlişsiler Uygulamaları

\begin{tabular}{|c|c|}
\hline Etnosentrik Uyuglamalar & Polisentrik Uygulamalar \\
\hline $\begin{array}{l}\text { İki yönlü iletişimi sağlayabilmek için üst düzey } \\
\text { yöneticilerle çalışılması }\end{array}$ & $\begin{array}{l}\text { Belirli bir ülkenin değer sistemleri ve lojistiğine } \\
\text { uygun yerel halkla iliskkiler programlarının } \\
\text { oluşturulması ve yürütülmesi }\end{array}$ \\
\hline $\begin{array}{l}\text { Üst düzey yöneticilerin halkla ilişskileri de etkileyen } \\
\text { küresel iş kararları hakkında bilgi vermeleri ve } \\
\text { kurumsal misyona uygun halkla ilişkiler hedeflerinin } \\
\text { yürütülmesi }\end{array}$ & $\begin{array}{l}\text { Yerel etkinliklerin doğrudan küresel hedeflerle } \\
\text { çelişmemesinin sağlanması }\end{array}$ \\
\hline $\begin{array}{l}\text { Halkla ilişkilerin dünya çapında entegre olmasının } \\
\text { sağlanması için üst düzey yöneticilerle çalışılması }\end{array}$ & $\begin{array}{l}\text { Kamuların tanımlanması ve potansiyel yerel konuların } \\
\text { görülebilmesi için yerel araştırma mekanizmasının } \\
\text { oluşturulması }\end{array}$ \\
\hline $\begin{array}{l}\text { Halkla ilişkiler uygulayıcılarının yerel yöneticilerle } \\
\text { yakın bir işbirliği içinde çalışmalarının sağlanması }\end{array}$ & $\begin{array}{l}\text { Genel merkezden gelen mesajların uygun yerel } \\
\text { mesajlara uyarlanması }\end{array}$ \\
\hline $\begin{array}{l}\text { Tüm yöneticilerin küresel itibarı anlamaları ve entegre } \\
\text { halkla ilişkilere destek olmaları için gereken eğitimin } \\
\text { sağlanması }\end{array}$ & $\begin{array}{l}\text { Misyonun, halkla ilişkilerin anlaşılması ve ev sahibi } \\
\text { ülkede işletmenin etkin bir şekilde temsil edilebilmesi } \\
\text { için, yerel üst düzey yöneticinin yetiştirilmesine } \\
\text { yardımcı olunması }\end{array}$ \\
\hline $\begin{array}{l}\text { Halkla ilişkiler faaliyetleri ve kamuoyu araştırması ile } \\
\text { ilgili genel ama esnek kuralların oluşturulması }\end{array}$ & $\begin{array}{l}\text { Yerel konular hakkında geri bildirimin sağlanması, } \\
\text { fikir alı̧verişine ve potansiyel sınır ötesi sorunların } \\
\text { çözümüne katkı sağlamak için küresel halkla ilişkiler } \\
\text { ekibine katılımının sağlanması }\end{array}$ \\
\hline \multicolumn{2}{|l|}{$\begin{array}{l}\text { Dünya çapında tüm halkla ilişkiler görevlileri için } \\
\text { halkla ilişkiler eğitiminin oluşturulması ve } \\
\text { uygulanması }\end{array}$} \\
\hline \multicolumn{2}{|l|}{$\begin{array}{l}\text { Küresel halkla ilişkiler ekibinin üyeleri arasında ekip } \\
\text { çalışmasının, bilgi paylaşımının ve fikir alışveriş } \\
\text { sürecinin teşvik edilmesi }\end{array}$} \\
\hline \multicolumn{2}{|l|}{$\begin{array}{l}\text { Konuların ve kriz iletişim prosedürlerinin önceden } \\
\text { belirlenebilmesi için küresel ekip ve diğer üst düzey } \\
\text { yöneticilerle (line manager) çalışılması }\end{array}$} \\
\hline \multicolumn{2}{|l|}{$\begin{array}{l}\text { Küresel halkla ilisskiler birimleri için hesap verebilirlik } \\
\text { programlarının oluşturulması ve izlenmesi }\end{array}$} \\
\hline $\begin{array}{l}\text { Küresel kurallarda önemli yerel esnekliğe izin } \\
\text { verilmesinin sağlanması }\end{array}$ & \\
\hline
\end{tabular}

Kaynak: Wakefield, 2001: 645`den uyarlanmıştır.

Tablo 1'de gösterilen etnosentrik yönetim modeline göre genel merkezdeki halkla ilişkiler uygulayıcıları kurumsal misyona uygun halkla ilişkiler hedeflerini yürütmekte, yerel yöneticilerle yakın bir işbirliği içinde çalışmakta, küresel itibar, kamuoyu araştırması, eğitim, konu ve kriz yönetim politikalarını belirlemekte ve hesap verebilirlik programlarını oluşturmaktadır. Polisentrik yönetim modelinde ise yerel halkla ilişkiler uygulayıcıları merkez şube çalışanlarıyla sıkı bir işbirliği içinde çalışmakta, onları yerel sorunlar hakkında bilgilendirmekte, kendi pazarları için yerel programlar oluşturmakta ve yürütmekte, genel merkezden gelen mesajları uygun yerel mesajlara çevirmekte, kamuların tanımlanması ve potansiyel yerel konuların görülebilmesi için yerel araştırma mekanizmaları oluşturmaktadır (Wakefield, 2001: 645). 
Wakefield'e (2001: 644) göre çok uluslu şirketlerdeki etkili halkla ilişkiler uygulamalarında yerel ve uluslararası programlar birleştirilerek tek bir işlev olarak sunulmaktadır. Bunun için uluslararası uzmanlık kazanmış uygulayıcılar hem küresel hem de yerel düzeyde yakın bir işbirliği içinde çalışmalarını sürdürürler. Uygulayıcıların itibar, iletişim ve aktivizmin küresel doğasını anlamaları, onların dünyanın her yerindeki fırsatları ve zorlukları öngörme ve bunlara cevap verebilmelerini sağlamaktadır (Wakefield'e (2001: 644). Uzmanlar; sınırların ötesinde işletmenin itibarını korumak, tutarlı mesajların ve örgütsel kimliğin sürdürülmesini sağlamak, sorunları öngörmek ve ele almak için küresel stratejiler oluştururken, her ülkedeki halkla ilişkiler uygulaycısı da yerel kültürel bağlam içinde ana şirketle sürekli geribildirimde ve fikir alışverişinde bulunarak etkin bir çalı̧̧ma sunmaktadır (Wakefield, 2001: 644).

Halkla ilişkiler biriminin bu çalışmaları etkin bir şekilde yürütmesi, şirket içindeki halkla ilişkiler biriminin yapılanmasıyla yakından ilişkilidir. Halkla ilişkiler işlevleri için tüm örgütler ve tüm ortamlar için ideal olacak bir örgütsel yapı tasarlanamaz (Dozier ve Grunig, 2005: 424). Yazarlara göre halkla ilişkiler işlevi tek bir departman altında toplandığında, uygulayıcılar kamuları ve iletişim kanallarını dinamik olarak tanımlamak için gerek duydukları özerklik ve yetkiyi bulabilirler. Uygulayıcılar ancak böyle bir çerçeve içinde rutinleşmiş iletişimin ötesine geçerek, amaçlı halkla ilişkilere ve stratejik sorun çözümüne odaklanabilirler (Dozier ve Grunig, 2005: 424).

Stratejik iletişim yönetimi (White ve Mazur, 1995) olarak tanımlanan halkla ilişkilerde uygulayıcı, örgütün içinde bulunduğu ortamı tanımlamakta, paydaşları (Freeman, 1984) ve stratejik kamuları belirlemekte, gündemi, sorunları ve iletişim programlarını stratejik olarak yönetmekte (Grunig ve Repper, 2005: 131) ve karar vericilere danışmanlık yapmaktadır (Warnaby ve Moss, 2004:7). Burada halkla ilişkiler uygulayıcılarının kurum içindeki rolleri ve görevleri, yapılan uygulamaların stratejik iletişim yönetimi çerçevesinde gerçekleştirilip gerçekleştirilmediğini göstermektedir. Halkla ilişkiler literatürüne göre halkla ilişkiler uygulayıcılarının standart davranış kalıpları ile gündelik uygulamaları ve etkinlikleri halkla ilişkiler uygulayıcılarının rolleri olarak tanımlanmaktadır (Dozier, 2005:349). Bu roller, başlangıçta kurum adına kamuda iyi niyet oluşturmaya odaklanan teknik uygulamalardan, örgütün içinde bulunduğu ortamı analiz eden, alternatif örgütsel tepkiler üzerinde değerlendirme yapan (Grunig, 2005b: 529) paydaşlar, kamular ve gündemlerle ilgili tepe yönetiminin strateji oluşumuna girdi sağlayan stratejik rollere dönüşmüştür (Moss ve Warnaby, 2004; Dozier, 2005).

1990'lı yıllara kadar halkla ilişkiler uygulamalarının tanımlanmasında ikili rol tipolojisi olarak da adlandırılan yönetici ve teknisyen rol tipolojisi (Broom ve Smith, 1979 ve Dozier, 1984) egemen çerçeve olarak kabul edilmekteydi. Ancak daha sonra yapılan çalışmalarda halkla ilişkiler uygulamalarının tanımlanmasında literatüre yeni roller girmiştir. Wright (1995) çalışmasında tepe yönetime rapor veren "iletişim yöneticisi" rolünü tespit ederken, Dozier ve Broom (1995) ise "uzman danışman" rolünü ve Steyn (1999) "halkla ilişkiler stratejist” rolünü açıklamıştır. Grunig ve Grunig'in 
(2005: 322) yapıtıkları açıklamaya göre, başında bir teknisyen yerine bir yöneticinin bulunduğu, çift yönlü simetrik model konusunda eğitimli uygulayıcıların çalıştığı halkla ilişkiler departmanları daha büyük potansiyel taşırlar.

\section{YÖNTEM}

$\mathrm{Bu}$ çalışmanın amacı Türkiye'de bulunan çok uluslu şirketlerdeki halkla ilişkiler strateji ve uygulamalarının uluslararası halkla ilişkiler çerçevesinde ele alınıp alınmadığı sorusuna açıklık getirmektir. Bunun için çok uluslu şirketlerin Türkiye'de bulunun şubelerindeki halkla ilişkiler uygulayıcıları ve yapılan uygulamalar sorgulanmış, uygulayıcıların merkez şirketle ve uluslararası arenada diğer halkla ilişkiler uygulayıcılarıyla kurdukları iletişim irdelenmiştir. $\mathrm{Bu}$ amaç doğrultusunda mülakatlarda kullanılması için "Çok uluslu şirketlerin Türkiye'de bulunan yerel şubelerindeki halkla ilişkiler uygulamaları küresel mi yoksa yerel uygulamalardan mı oluşmaktadır?”, "Halkla ilişkiler departmanı çeşitli iletişim etkinliklerinin düzenlenmesinde genel merkezden bağımsız kararlar alabilir mi?", "Halkla ilişkiler departmanın temel halkla ilişkiler uygulamaları nelerdir?" ve "Halkla ilişkiler uygulamaları için halkla ilişkiler ajanslarından destek alınıyor mu? soruları geliştirilmiştir.

Araştırmanın çalışma grubunu otomotiv ${ }^{\ddagger}$ sektörü oluşturmaktadır. Otomotiv sektörünün belirlenmesindeki kriterler ise; en büyük 100 çok uluslu şirketin yüzde 13'ünü motorlu kara taşıtlar oluşturması, sektördeki bütün markalara Türkiye'de ulaş1labiliyor olması, sektörün dinamik olması ve daha sonra yapılacak sektörlerarası çalışmalar için karşılaştırma imkânı sağlamasıdır. Araştırma kapsamında Fortune Global 500 (2012) şirket sıralamasında yer alan 17 otomotiv markasının Türkiye'de bulunan şubeleriyle görüşme talebinde bulunulmuştur. Bu talepleri onaylayan 9 çok uluslu şirketin halkla ilişkiler uygulayıcıları veya iletişim yöneticileriyle 04. Ekim 2012 - 22. Ocak 2013 tarihleri arasında 45-60 dakika süren görüşmeler yapılmıştır. 4 şirket kesinlikle katılmak istemediğini bildirmiş ve diğer 4 şirket için ise alınan randevular şirketten kaynaklanan nedenlerden dolayı (yoğun çalışma ortamından kaynaklı randevu ertelenmeleri) gerçekleşmemiştir.

Görüşülen şirketler ve halkla ilişkiler uyglayıcılarının unvanları sırasıyla Mazda - PR Uzmanı, Hyundai - PR Uzmanı, Mercedes-Benz - Kurumsal İletişim Departmanı Grup Şefi, Fiat - Basınla İlişkiler Uzmanı, Ford - Kurumsal İletişim Ekip Lideri, Honda - Kurumsal İletişim Uzmanı, Toyota Kurumsal İletişim Koordinatörü, Opel - Dış İlişkiler Direktörü ve Peugeot - Basın ve Halkla İlişkiler Direkörü olmuştur.

Görüşme kılavuzu takip edilerek yöneltilen yapılandırılmış görüşme formundaki açık ve kapalı uçlu sorular üç bölümden oluşmaktadır. Birinci bölüm; birim üyelerinin demografik bilgilerine

En büyük 100 çok uluslu şirket küresel mal ticaretinin yarısını kontrol etmektedir. Bu şirketler sektör bazında değerlendirildiğinde motorlu kara taşıtlar (yüzde 13), petrol (yüzde 10), elektriksel araç gereçler (yüzde 9), yiyecek, içecek ve tütün (yüzde 9), ilaç (yüzde 9), kamu hizmetleri (yüzde 9), telekomünikasyon (yüzde 8) alanlarında yoğunlaşmaktadır (UNCTAD, 2009: 19). 
yönelik soruları içerirken, ikinci bölüm; halkla ilişkiler departmanını sorgulamaktadır. Üçüncü bölüm ise, halkla ilişkiler stratejilerine ve uygulamalarına yöneliktir. Burada hangi durumlarda küresel veya yerel stratejilerin uygulandığı, yerel stratejilerin belirlenmesi durumunda merkezden onayın alınıp alınmadı̆̆ı, küresel stratejiden farklı ne tür uygulamaların yapıldığı öğrenilmeye çalışılmıştır.

\section{BULGULAR}

\subsection{Katılımcıların Demografik Özellikleri}

Araştırmaya katılan halkla ilişkiler uygulayıcılarının 6'sı kadın 3'ü erkektir. Yaşları 29 ile 46 arasında değiş̧en katılımcıların lisans eğitimleri İşletme, Endüstri Mühendisliği, İktisat, Pazarlama ve İletişim alanlarındandır. Yüksek lisans eğitimi aldıklarını belirten 3 katılımcının uzmanlık alanları ise Pazarlama, Ekonomi ve İşletmedir. Katılımcıların hepsi ileri düzeyde İngilizce dil bilgisine sahip iken, katılımcıların çoğu ikinci bir yabancı dil (Almanca, İtalyanca veya Fransızca) bildiklerini belirtmişlerdir. Halkla ilişkiler uygulayıcılarının mevcut kuruluşlarda çalışma süreleri en az 1 yıl, en fazla 14 yıldır.

\subsection{Otomotiv Şirketlerine İlişkin Genel Bilgiler}

Görüşmeyi kabul eden halkla ilişkiler uygulayıcılarının çalıştıkları şirketlerin Japonya (3), Amerika (2), Kore (1), Almanya (1), İtalya (1) ve Fransa (1) merkezli olmas1 dünya otomotiv sektöründe üç kıtanın temsilini sağlamıştır.

Tablo 2. Şirketlerin Türkiye'de Faaliyete Başladıkları Yıllar, Çalışan Sayıları ve Şirket Sermayesi

\begin{tabular}{|l|l|l|l|}
\hline Şirket & $\begin{array}{l}\text { Faaliyete } \\
\text { Başlanan Yıl }\end{array}$ & $\begin{array}{l}\text { Çalışan } \\
\text { Sayıları }\end{array}$ & Şirket Sermayesi \\
\hline K1 & 1996 & 20 & Yabanc1 Sermaye (\%100 Japonya) \\
\hline K2 & 1997 & 5000 & Türk - Yabanc1 Sermaye Ortakl1 (\%75 Kore, \%25 Türk) \\
\hline K3 & 1967 & 5000 & Yabanc1 Sermaye (\%100 Almanya) \\
\hline K4 & 1968 & 8000 & Türk - Yabanc1 Sermaye Ortakl1 (\%51 İtalya, \%49 Türk) \\
\hline K5 & 1959 & 9800 & $\begin{array}{l}\text { Türk - Yabanc1 Sermaye Ortakl1 (\%49 Türk, \%49 Amerika, } \\
\text { \%2 Halka Arz) }\end{array}$ \\
\hline K6 & 1992 & 2000 & Yabanc1 Sermaye (\%100 Japonya) \\
\hline K7 & 1991 & 200 & Yabanc1 Sermaye (\%100 Suudi Arabistan) \\
\hline K8 & 1990 & 80 & Yabanc1 Sermaye (\%100 Amerika) \\
\hline K9 & 2002 & 150 & Yabanc1 Sermaye (\%100 Frans1z) \\
\hline
\end{tabular}

Tablo 2'ye göre araştırma kapsamında görüşülen şirketlerin Türkiye'de faaliyete başlamaları 1959 ile 2002 yılları arasında değişmektedir. Bu şirketlerde çalışan sayıları en az 20 en fazla 9800 kişidir. Çalışan sayıları arasındaki bu farklılık şirketlerin operasyon tiplerine göre değişim göstermektedir. Lisans, distribütörlük veya yabancı sermaye ${ }^{\S}$ şeklindeki operasyon tiplerinde daha az

\footnotetext{
${ }^{\S}$ Yabancı ülke(ler)de yeni bir şirketin kurulması veya var olan yerli bir şirketin satın alınması, arazi, üretim tesisi gibi fiziki değerler edinilmesi doğrudan yabancı sermaye yatırımlarını oluşturur. Doğrudan yabancı sermaye
} 
çalışan sayısı söz konusu iken, ortak girişim olarak yönetilen şirketlerdeki çalışan sayıları çok daha fazladır. Şirketlerin büyük çoğunluğu yabancı sermaye yapısına sahip iken üç şirketin Türk - Yabancı sermaye ortaklı̆̆ 1 vardır.

\subsection{Halkla İlişkiler Departmanı}

Halkla ilişkiler uygulayıcıları ile yapılan görüşmelerde halkla ilişkiler departmanının örgütsel yapı içerisindeki konumu, departmanda çalışan sayıları ve bu kişilerin aldıkları görevler, departmanın bağlı olduğu birim veya kişi, departman bütçesi, departmanın ajans desteği alıp almadığıyla ilgili sorular sorulmuştur. Halkla ilişkiler departmanının isimlendirilmesi, bağlı olunan birim veya kişi, çalışan sayıları ve görevlerine ilişkin ifadeleri tablo 3'de görülmektedir.

Tablo 3. Halkla İlişkiler Departmanının İsimlendirilmesi, Bağlı Olunan Birim veya Kişi, Çalışan

\section{Sayıları ve Unvanları}

\begin{tabular}{|c|c|c|c|c|}
\hline Şirket & Departman Adı & $\begin{array}{l}\text { Departmanın Bağlı } \\
\text { Olduğu Birim/Kişi }\end{array}$ & $\begin{array}{l}\text { Çalışan } \\
\text { Sayısı }\end{array}$ & Çalışanların Unvanları \\
\hline K1 & PR Departmanı & Genel Müdür & 2 & Direktör, Uzman \\
\hline K2 & PR Departmanı & $\begin{array}{l}\text { Marketing } \\
\text { Communication } \\
\text { Müdürü }\end{array}$ & 2 & Müdür, PR uzmanı \\
\hline K3 & $\begin{array}{l}\text { Kurumsal İletişim } \\
\text { Departmanı }\end{array}$ & CEO & 6 & $\begin{array}{l}\text { Yönetici, Ürün Gruplarından Sorumlu } \\
\text { Uzman (2), Marka Sosyal Medya } \\
\text { Sorumlusu, Kurumsal Sosyal Medya } \\
\text { Sorumlusu, Stajyer }\end{array}$ \\
\hline K4 & $\begin{array}{l}\text { Kurumsal İletişim } \\
\text { Direktörlüğ̈u }\end{array}$ & CEO & 6 & $\begin{array}{l}\text { Direktör, Yönetici - Basın ve } \\
\text { Organizasyon (2), Uzman - Basın ve } \\
\text { Organizasyon (2), Birim Sekreteri }\end{array}$ \\
\hline K5 & $\begin{array}{l}\text { Kurumsal İletişim } \\
\text { Müdürlüğü }\end{array}$ & $\begin{array}{l}\text { İnsan Kaynakları ve } \\
\text { Kurumsal İletişim } \\
\text { Direktörü }\end{array}$ & 8 & $\begin{array}{l}\text { Müdür, Kurumsal İletişim Ekip Lideri, } \\
\text { Sosyal Sorumluluk ve Sponsorluk } \\
\text { Uzmanı, Kurumsal İletişim Uzmanı, } \\
\text { Sosyal Medya Uzmanı, İç İletişim } \\
\text { Uzmanı, Etkinlik ve Organizasyon } \\
\text { Sorumlusu, Departman Asistanı }\end{array}$ \\
\hline K6 & $\begin{array}{l}\text { Kurumsal İletişim } \\
\text { Departmanı }\end{array}$ & Genel Müdür & 2 & Müdür, PR Uzman \\
\hline K7 & $\begin{array}{l}\text { Kurumsal İletişim } \\
\text { Müdürlüğü }\end{array}$ & Pazarlama Direktörü & 2 & Müdür, Koordinatör \\
\hline K8 & $\begin{array}{l}\text { Diş İlişkiler } \\
\text { Direktörlüğ̈̈ }\end{array}$ & Genel Müdür & 4 & $\begin{array}{l}\text { Direktör, Medya İlişkileri Uzmanı, } \\
\text { Basın Filosu Araç Koordinatörü, Asistan }\end{array}$ \\
\hline K9 & $\begin{array}{l}\text { Basın ve Halkla } \\
\text { İlişkiler Direktörlüğü }\end{array}$ & Genel Müdür & 3 & Direktör, Uzman, Stajyer \\
\hline
\end{tabular}

Halkla ilişkilerin ne anlama geldiği konusunda hem eğitimciler hem de uygulayıcılar arasında sağlanamayan konsensüs halkla ilişkiler departman adlandırmasına ve uygulayıcıların unvanlarına da 
yansımaktadır. Tablo 3'e göre halkla ilişkiler uygulayıcıları "PR Uzmanı", "Kurumsal İletişim Uzman1/Koordinatörü/Ekip Lideri/Grup Şefi”, "Basınla İlişkiler Uzmanı/Direktörü”, "Basın ve Halkla İlişkiler Direktörü” ve "Dış İlişkiler Direktörü” gibi farklı unvanlar taşımaktadır. Türkçede yaygın olarak kullanılan "halkla ilişkiler" sadece bir kişinin unvanına yansımıştır. Ayrıca halkla ilişkiler uzmanı yerine "PR Uzmanı" adlandırması dikkat çekmiştir.

Şirket içindeki halkla ilişkiler departmanı için en fazla "Kurumsal İletişim Departmanı", “Kurumsal İletişim Müdürlüğü” ya da "Kurumsal İletişim Direktörü” kullanılmaktadır. İki şirket "PR Departmanı" isimlendirmesini kullanırken, bir şirket "Dış İlişkiler Direktörlüğ̈̈” ve bir şirket de “Basın ve Halkla İlişkiler Direktörlüğü”nü kullanmaktadır.

Halkla ilişkiler departmanlarının bağlı oldukları birim ya da kişi değerlendirildiğinde, departmanların büyük çoğunluğunun doğrudan üst yönetime bağlı oldukları görülmektedir.

Katılımcılara halkla ilişkiler departman bütçesinin toplam bütçe dağılımı içerisindeki \% oranı sorulduğunda, birçok katılımcı cevap vermek istememiştir. Cevap verenler ise, halkla ilişkiler departman bütçesinin toplam bütçe dağılımı içerisindeki oranının yıllık \%5 civarında olduğunu belirtmişlerdir.

Halkla ilişkiler uygulayıcılarına halkla ilişkiler ajanslarından ne tür destek alındığ sorulduğunda katılımcılar uygulamaların “inhouse” yürütüldüğünü belirtmiş ancak özel projelerde, "event"lerin organizasyonunda, medya takibinde ve danışmanlık hizmetleri gibi ihtiyaçlar için birden fazla halkla ilişkiler ajansından destek aldıklarını ya da hizmet talep ettiklerini belirtmişlerdir. Sadece tek bir şirket ajans desteği almadığını ifade etmiştir.

\subsection{Halkla İliş̧kiler Uygulamaları}

Yapılan görüşmelere göre halkla ilişkiler uygulamalarının merkezinde çalışanlarla iletişim ve medya ilişkileri bulgulanmıştır. Ancak uygulayıcıların online PR, sponsorluk, sosyal sorumluluk, konu yönetimi ve kriz yönetimi uygulamaları da vardır. Katılımcıların kurum içi iletişime yönelik ifadeleri aşağıda belirtildiği gibidir:

K1: Kurum içi e-mail ile bilgi paylaşımı yapılıyor, firma hakkında basında ve sosyal medyada çıkan haberler ve gelişmelerden haberdar ediliyor."

K2: "Basın ile aynı anda tüm çalışanlara haber akışı, ürünler ve lansmanlar vs. ile ilgili bilgilendirmeler yapıllyor; yurtdışından gelen global basın bültenleri servis ediliyor.”

K3: "Çalışanlarımızın, şirketteki gelişmeler hakkında zamanında ve yeterli miktarda bilgilendirilmesini önemsiyoruz. Kurum içi newsletter uygulamasında medyada çıkan haberler çalışanlarımızla paylaşıllyor; dı̧̧arıya kurumsal newsletter uygulamamız var." 
K4: “... web ve ... gazete aracıllğı ile iletişsim kuruyoruz. Kurum içi çalışanlara bilgi akışı sağlanıyor. Özel iç iletişim çalışmaları planlanıyor."

K5: “Tüm paydaşlara (basın, çalışanlar, yatırımcılar...) iletişim faaliyetleri yürütüllüyor. Basına, ya da basina kapalı konular ile ilgili beyaz yakalılara elektronik ortamda, mavi yakalara panolar aracıll̆̆ıyla bilgilendirme yapılıyor."

K6: "Kurum içi düzenli e-mail gönderimi ile bilgilendirme yapıllyor. Yıl sonu toplantıları organize ediliyor. Basın bültenleri yayınlanıyor, röportajlar organize ediliyor."

K7: "Kurum içi iletişim insan kaynakları tarafından yapılıyor. Kurum dışı iletişimde basın aktiviteleri, üniversite ve diğer kurumlarla işbirlikleri yapıllyor. Basın bülteni gönderimi yapılyyor, demeç ve röportajlar, gezi organizasyonları düzenleniyor."

K8: "Şirket içi e-mail ve panolar kullanılıyor. Aynı zamanda bayilerde, showroomlar'da da panolar ve basın haberlerinden oluşan kitapçıklar var."

K9: “CEO iletişimi, kurumsal açıklamalar, kurum içi bülten, newsletter gönderimi, bayi iletişimi yapıllyor..."

Katılımcılar, paydaşlarla etkili bir iletişim kurmak için özellikle ekonomi ve otomotiv basını ile olan ilişkilere büyük önem verdiklerini ifade etmişlerdir. Halkla ilişkiler uygulayıcılarının medya ilişkilerine ilişkin ifadeleri aşağıda belirtildiği gibidir:

K1: "Basına test araçlarının verilmesiyle haber yansımaları alınıyor. Basına basın bültenleri servis ediliyor; yurtdlşında .... tarafindan gerçekleştirilen workshoplara ve otomobil fuarlarına ilgili konuya hâkim basın mensuplarını götürüyoruz.",

K2: "Ana iş, medya iliş̧kilerinde basın ile ilişkilerinin geliştirilmesi... yurtiçi ve yurtdışı gezi ve test sürüşü organizasyonlarının düzenlenmesi."

K3: "Medya ilişkilerinde ekonomi ve otomotiv basını ile ilişsiler yürütülüyor."

K4: "Ekonomi ve otomotiv basını ile ilişkiler yürütülüyor."

K5: “Ana iş bu. Basın toplantıları, özel röportajlar, gezilerle basına sürekli bilgi aktarımı yapılarak ilişkiler sıcak tutuluyor."

K6: "Ekonomi ve otomotiv basın mensuplarının gezi ve test sürüşlerine davet edilmesi, yurtdışında ă̆ırlanmaları ve fabrika gezilerinin düzenlenmesi.",

K7: "Birçok farkl yöntemle ürün ve kurumsal bilgilendirmeler yapılyyor."

K8: "Sürekli bir ilişsi var. Basın bültenleri servis ediliyor, ürün ve kurumsal sorulara cevaplar veriliyor." 
K9: "Sürekli yüz yüze iletişim kurulmakta, yemek ve röportaj düzenlenmekte. Basın bültenleri gönderilmekte, test sürüş organizasyonları yapılmakta."

\subsection{Halkla İlişkiler Stratejisi}

Yapılan araştırmaya göre uluslararası arenada uygulanan halkla ilişkiler polisentrik, regiosentrik ve geosentrik yönelimlerde yoğunlaşmaktadır. Etnosentrik yönelim ise bulgulanmamıştır. Uygulayıcıların bu yönelimlerden faydalanmaları, ancak şubelerarası çok yönlü iletişimin kurulmasıyla mümkün kılınmaktadır.

K1: “Japonya ile herhangi bir bağlantımız yoktur. Merkez (Almanya) yıllık ajanda veriyor... $P R$ departmanı zaman ve bütçeyi düzenleyip bir planlama yapıyor. Bağımsız yürütülen projelerde yapılan uygulamalar ve sonuçlar görseller ile birlikte Almanya'ya raporlanıyor. Genelde Almanya'dan gelen direktifler uygulaniyor (bölgesel) ve yerel uygulamalar Türkiye'deki fuar katılımları veya sponsorluklar oluyor. Kullanılan yaklaşım ve materyaller \%80 yurtdışında hazırlanıp geliyor."

K2: "Genel merkez ve bölge merkeziyle sürekli bir ilişki var. Direktiflerin tamamı yurt dışından geliyor, ya da onay alınıyor. CEO Koreli olduğu için bağımsız hareket edilmiyor. Strateji belirleniyor, lokal uygulamalar ile ilgili öneri yapllyyor, öneriler yine KORE tarafindan değerlendirilip onaylanıyor. Bă̆ımsız hareket edilmiyor!

Üretim anlamında bölgesel yaklaşım var, ancak PR konusunda Modern Premium Felsefesi tüm dünyada iletişimin ana çatışını oluşturuyor."

K3: "Müşteri ve talepler farklı olduğu için genel merkeze bağlllık sınırlı, bağımsız kararlar alıniyor."

K4: "Genel merkezle iliş̧kimiz var, ancak esnek ve bă̆ımsız kararlar alınabiliyor."

K5: "Genel merkez ve bölge merkeziyle ilişkimiz var. Ancak sadece bilgilendirme yapıllyor, kararlar tamamen bağımsız alınıyor. Global zaman planlamalarına uygun hareket edilmeye çalışılıyor. Yerel, küresel strateji oranı çok değiş̧enlik gösterdiğinden, net bir rakam verilmesi çok zor!"

K6: "Direktiflerin tamamı yurt dışından geliyor, ya da onay alınıyor. CEO Japon olduğu için bağımsız hareket edilmiyor."

K7: "Genel merkezle iliş̧kimiz yok. Bölge merkeziyle ilişkimiz var. Marka söylemlerinde tamamen bağımlı bir yapı var iken, yerel aktiviteler ve söylemlerde tamamen bağımsız hareket edilebiliyor."

K8:" Hem genel merkez hem de bölge merkeziyle ilişkilerimiz oluyor. Kurumun genel değerlerine aykırı olmamak koşulu ile genelde bağımsız hareket ediliyor." 
K9: "Genel merkezle ilişkimiz var. Ancak genelde bağımsız hareket ediliyor. Planlar üzerinde mutabık kalınıyor, tavsiyeler alınıyor."

\section{6.Çok Uluslu Otomotiv İşletmelerin Şubelerarası İletişim Akışları}

Yapılan görüşmelere göre çok uluslu şirketlerde iletişim ve bilgi akışının başarılı bir şekilde işlemesine yönelik üç temel tutum tanımlanmaktadır. Bunlar genel merkezden şubelere çok az sayıda talimatın, tavsiyenin ve yönlendirmenin yapıldığı polisentrik oryantasyon; bölgesel şubeler ve ülkelerarası yüksek sayıda talimat, emir, tavsiyenin yapıldığı regiosentrik oryantasyon ve küresel düzeyde hem genel merkezle hem de şubelerarası bilgi akışının gerçekleştiği geosentrik oryantasyondur.

Araştırmaya katılan halkla ilişkiler uygulayıcıları şirketin genel merkezde ve/veya bölge merkezinde çalışan halkla ilişkiler uygulayıcıları ile her gün e-mail ve/veya telefonla düzenli bilgi akışında bulunduklarını ve çeşitli organizasyonlar ve konferanslar ya da özel amaçlı ziyaretlerle bir araya geldiklerini ifade etmişlerdir.

K1: "Bölge merkezinde çalışan halkla ilişkiler uygulayıcıları ile e-mail, telefon görüşmeleri yapılıyor, toplantılar düzenleniyor."

K2: "Genel merkezde ve bölge merkezinde çalışan halkla ilişkiler uygulayıcıları ile neredeyse her gün e-mail veya telefon ile iletişim kuruluyor. Yllda bir defa Global PR Conference düzenleniyor, özel amaçlı ziyaretler (örneğin Auto Show) yapılıyor."

K3: "Genel merkezde çalışan halkla ilişkiler uygulayıcıları ile neredeyse her gün e-mail veya telefon ile iletişimimiz oluyor. Özel aktivite ve organizasyonlarda bir araya geliniyor. CEO bazında her gün iletişim oluyor. Bölge merkezinde çalışan halkla ilişkiler uygulayıcıları ile iletişimimiz olmuyor."

K4: "Genel merkezde çalışan halkla ilişkiler uygulayıcıları ile her ay düzenli raporlama yapılıyor. Aralarda gerekli olduğunda görüşülüyor. E-mail ağırlıklı iletişsimimiz oluyor, gerektiğinde telefon görüşmeleri yapıyoruz."

K5: "Genel merkezde ve bölge merkezinde çalışan halkla ilişkiler uygulayıcıları ile iletişimimiz var."

K6: "Genel merkezde çalışan halkla ilişkiler uygulayıcıları ile her gün e-mail veya telefon ile iletişim kuruyoruz."

K7: "Bölge merkezinde çalışan halkla ilişkiler uygulayıcıları ile her gün e-mail, nadiren telefon görüşmeleri yapıllyor. Ağırlıklı iletişim akışı Belçika'dan oluyor. Brief'ler ve yönlendirmeler geliyor, Türkiye'den bilgilendirme gönderiliyor." 
K8: "Genel merkezde çalışan halkla ilişkiler uygulayıcıları ile gerekli olduğunda e-mail veya telefon görüşmeleri oluyor. Bölge merkezinde çalışan halkla ilişkiler uygulayıcıları ile her gün e-mail ve telefon görüşmeleri yapıllyor."

K9: "Genel merkezde çalışan halkla ilişkiler uygulayıcıları ile her gün e-mail ile iletişim kuruyoruz. Bölge merkezinde çalışan halkla ilişkiler uygulayıcıları ile iletişimimiz olmuyor."

\section{SONUÇ VE DEĞERLENDİRME}

Otomotiv sektöründe faaliyette bulunan ve Türkiye'de şubesi olan çok uluslu şirketlerin halkla ilişkiler uygulayıcıları ile yapılan araştırmaya göre şirketlerin halkla ilişkiler departmanlarının çoğu “Kurumsal İletişim Departmanı/Müdürlüğü/Direktörü” olarak adlandırılmaktadır. Bu bulguyu 1990’l1 yılların başlarında Communication World ve pr reporter'ın ortaklaşa yaptıkları çalışma desteklemektedir (Turney, 2009). Yapılan çalışmaya göre ABD’nin en büyük 539 şirketinde halkla ilişkiler birimleri için en fazla "communication" (iletişim) ya da "corporate communication" (kurumsal iletişim) isimleri kullanılmaktadır. Çalışmada, 1920'lerde halkla ilişkiler birimleri için en çok tercih edilen "halkla ilişkiler" ismi ise ikinci sıraya gerilemiştir (Turney, 2009). Tercih edilen kavramlar arasında kuramsal bir farklılığın olmaması kavramların birbirlerinin yerine kullanılmasının herhangi bir sıkıntı yaratmadığını göstermektedir (Steyn, 2003: 169). Halkla ilişkiler kavramı şirketlerin iletişim etkinliklerini tanımlamakta kullanılan en eski kavram olsa da bugün birçok şirket, kısmen halkla ilişkilerin taşıdığı kötü çağrışımdan ötürü iletişim etkinliklerinden söz ederken geleneksel halkla ilişkiler yerine kurumsal iletişim kavramını tercih etmektedir (Grunig, 2005a: 1415). Bunu yapmasındaki amaç, halkla ilişkilerin tarihsel gelişim sürecinde tanıtım veya propagandayla bir tutulmasından ve kitlesel medyada yayınlanmak üzere basın bültenlerinin hazırlanması gibi basit bir çaba görüntüsünden kurtularak, halkla ilişkilere stratejik bir yaklaşım kazandırmaktır (Ehling, 2005: 482).

Dozier ve Grunig’e (2005: 424) göre halkla ilişkiler işlevi için tüm örgütler ve tüm ortamlarda ideal olacak bir örgütsel yapının tasarlanması mümkün değildir. Ancak halkla ilişkiler uygulamalarının tek bir departman altında toplanmasıyla, uygulayıcıların kamuları ve iletişim kanallarını tanımlamaları için gerek duydukları özerklik ve yetkiye sahip olmaları sağlanır. Uygulayıcılar, ancak böyle bir çerçeve içinde rutinleşmiş iletişimin ötesinde gerçek anlamda stratejik uygulamalara ve sorun çözümüne odaklanabilirler (Dozier ve Grunig, 2005: 424). Yapılan araştırma sonunda halkla ilişkiler departmanlarının bağlı oldukları birim ya da kişi değerlendirildiğinde, departmanların büyük çoğunluğunun doğrudan üst yönetime bağlı oldukları bulgulanmıştır. Bu durum departmanların özerk olduğunu ve karar alma sürecinde herhangi bir aracı birim ya da kişi olmadan doğrudan üst yönetime bilgi aktardıklarını göstermektedir. Halkla ilişkiler departmanının doğrudan üst yönetime bağlı olması, halkla ilişkilere stratejik bir yönelim kazandırmaktadır (Grunig, Grunig ve Ehling, 2005: 82). 
Halkla ilişkiler departmanlarında çalışan halkla ilişkiler uygulayıcı rolleri ve sayıları şirketten şirkete çeşitlenerek farklılık gösterse de belirlenen roller, Dozier (1984), Broom ve Smith'in (1979) çalışmalarında tutarlı olarak ortaya çıkan yönetici ve teknisyen rolleriyle ekonomik olarak özetlenmektedir. Burada yöneticiler, stratejik kararlar alarak halkla ilişkiler programlarının sonuçlarından sorumlu tutulurken, teknisyenler alınan kararların hayata geçirilmesini sağlayan iletişim ürünlerini üretmek gibi alt düzey bir mekaniği gerçekleştirirler (Dozier, 2005: 355). Yapılan çalışmada halkla ilişkiler uygulayıcı rolleri alan yazınında ikili tipoloji olarak da bilinen yönetici ve özellikle kurum içi iletişim uygulamalarında ve medya ilişkilerinde uzmanlaşmış teknisyenle tanımlanmıştır. Mevcut uygulamalarda geleneksel halkla ilişkiler anlayışının sürmesinin ve teknisyen rol seviyesinin değişmediğinin en önemli gerekçesi, uygulayıcıların kurum içi iletişim uygulamaları, medya ilişkileri, online PR ve sponsorluk gibi rutin uygulamaları yerine getirmeleri olmuştur. Bu duruma genel bir neden olarak çok uluslu otomotiv şirketlerinin küresel bir perspektifi koruyarak stratejileri ve direktifleri genel merkezden belirlemeleri, iletişim ve bilgi akışını küresel düzeyde genel merkezden şubelere ve şubeler arasında gerçekleştirmeleri ve Türkiye'deki halkla ilişkiler uygulayıcılarının da bu direktiflere genel hatlarıyla uymalarını istemeleri gösterilebilir. Ancak uygulayıcılar genel merkezde belirlenen stratejilere rağmen ülke ve ortam koşullarına uygun olduğuna inandıkları yerel uygulamaları uygulama özgürlüğüne sahiptir. Burada genel merkezden yürütülen bağımsız projeler (KSS uygulamaları, sponsorluk, sosyal medya uygulamaları) ve diğer uygulamalar (eventler) genel merkeze her gün e-mail ve/veya telefonla düzenli bilgi akışında bulunularak raporlanmaktadır. Şirketler iç ve dış paydaşlarla olan iletişim çabalarını genel olarak in-house yürütmektedir. Ancak kamuların dikkatini çekebilmek ve cazibe alanları oluşturmak için planlanan özel projelerde, "event”lerin organizasyonunda, medya takibinde ve danışmanlık hizmetleri gibi konularda kurum içi yapılanmaya ek olarak birden fazla bölgesel halkla ilişkiler ya da iletişim ajanslarından proje bazlı destek alınmakta ya da hizmet talep edilmektedir.

Araştırmaya katılan halkla ilişkiler uygulayıcılarının lisans eğitimleri İşletme, Endüstri Mühendisliği, İktisat, Pazarlama ve İletişim alanlarındandır. Erdoğan'a (2006: 212) göre alt düzey destek işlevleri olarak tanımlanan uygulamalar uzmanlık becerileri isteyen uygulamalardır. Elde edilen bulgular halkla ilişkilerin stratejik bir işlev kazanma sürecinin ve profesyonel halkla ilişkiler anlayışına yönelik bir bilincin Türkiye'de yerleşmesini veya başlamasını geciktirmekle birlikte yapılan uygulamaların teknik uygulamalarla sınırlı kalmasına neden olmaktadır. Oysa lisans düzeyindeki halkla ilişkiler eğitimi alan öğrencilere hem teknik bilgi ve beceriler hem de stratejik yönetim ile yöneticilik bilgisi verilmektedir. Böylece öğrenciler, hazırladıkları iletişim çalışmalarında bilimsel yöntemleri uygulama, konulara ve sorunlara rasyonel yaklaşım sunma ve ileride çalışacakları şirketleri veya kurumları çok iyi temsil etme becerisine sahip olmaktadırlar.

Araştırmaya göre şirketlerin halkla ilişkiler uygulamalarına yönelik üç temel yönelim bulgulanmıştır. Bunlar genel merkezden şubelere çok az sayıda talimatın, tavsiyenin ve 
yönlendirmenin yapıldığı polisentrik yönelim; bölgesel şubeler ve ülkelerarası yüksek sayıda talimat, emir ve tavsiye akışı gerçekleşen regiosentrik yönelim ve küresel düzeyde hem genel merkezle hem de şubelerarası çok yönlü bilgi akışının gerçekleştiği geosentrik yönelimdir (Heenan ve Perlmutter, 1979). Halkla ilişkilerin diğer ülkelerde menşei ülkeden farklı olmadığını varsayan salt etnosentrik yaklaşımın hiçbir şirket tarafından belirtilmemiş olması otomotiv sektöründe faaliyette bulunan çok uluslu şirketlerin halkla ilişkiler uygulamalarının diğer üç yönelimde yoğunlaştığını göstermektedir. Uygulayıcılar, bulunduğu ülke için uygun olduğuna inandığı yerel uygulamaları bölgesel veya küresel prensipler ve stratejilerle bir denge içinde uygulama özgürlüğüne sahip olmakta, bu yönelimler arasında, Vercic, Grunig ve Grunig'in (1996: 33) ifade ettikleri gibi, köprü kurarak bir karma yaklaşımından faydalanmaktadır. Bunun için uygulayıcılar diğer şubelerdeki ve genel merkezdeki uygulayıclar ile günlük telefon görüşmeleri yapmakta, e-mail yazışmalarında bulunmakta, konferans veya özel amaçlı ziyaretler gerçekleştirmektedir.

Wakefield'e (2009: 94) göre halkla ilişkiler uzmanlarının çoğu çok uluslu şirketlerde istihdam edilmektedir ve muhtemelen gelecekte yine bu şirketlerde çalışan halkla ilişkiler uygulayıcılarının sayısı daha da artacaktır. Vercic'in (2009: 804) ifadesine göre, “çok uluslu şirketler halkla ilişkilerin 'doğal' ortamıdır ve dünya sahnesindeki kurumsal halkla ilişkiler en iyi halkla ilişkilerin müjdesidir." Tüm bunlar, farklı sektörlerde faaliyette bulunan çok uluslu şirketlerin halkla ilişkiler uygulamalarının ve uluslararası konularının analizlerini ve karşılaştırmalarını mümkün kılacak daha fazla çalışmanın yapılması gerekliliğini ve ihtiyacını hissettirmektedir.

Nitekim bu çalışmada, Fortune Global 500 sıralamasına girmiş, otomotiv sektöründe faaliyette bulunan çok uluslu şirketlerin Türkiye yerelindeki halkla ilişkiler departmanları ve uygulamaları araştırılmıştır. Daha fazla sektörel bulgulara ve kuramsal yönlendirmelere ulaşabilmek için bundan sonraki çalışmalarda farklı sektörlerde faaliyette bulunan çok uluslu şirketlerdeki halkla ilişkiler departmanları ve uygulamaları araştırılmalıdır. Böylece hangi sektörlerin yerelleşme, hangilerinin küreselleşme gereksinimlerine parallel olarak geliştirdikleri küresel ve/veya yerel uygulamalar tespit edilerek hem literatüre hem de uyglamaya yönelik katkı sağlanabilir.

\section{KAYNAKÇA}

Bartlett, C.A. ve Ghoshal, S. (1989) “Managing Across Borders: The Transnational Solution”, Boston, Harvard Business School Press.

Berndt, R., Altobelli, C.F. ve Sander, M. (2010) “Internationales MarketingManagement”, Berlin, Springer Verlag, 4. Auflage. 
Brinkerhoff, D.W. ve Ingle, M.D. (1989) "Integrating Blueprint and Process: A Structured Flexibility Approach to Development Management", Public Administration and Development, 9(5), 487503.

Broom, G.M. ve Smith, G.D. (1979) “Testing the Practitioner's Impact on Clients”, Public Relations Review, 5(3), 47-59.

Chakravarthy, B.S. ve Perlmutter, H.V. (1985) "Strategic Planning for a Global Business", Columbia Journal of World Business, Summer, 20, 3-10.

Dozier, D.M. (1984) “Program Evaluation and Roles of Practitioners”, Public Relations Review, 10(2), 13-21.

Dozier, D.M.ve Broom, G.M. (1995) "Evolution of the Manager Role in Public Relations Practice", Journal of Public Relations Research, 7(1), 3-26.

Dozier, D.M. (2005) “İletişim ve Halkla İlişkiler Uygulayıcılarının Örgütsel Rolleri”, Grunig vd. (edt.), Halkla İlişkiler ve İletişim Yönetiminde Mükemmellik, İstanbul, Rota Yayın Dağıtım Tanitım, 349-378.

Dozier, D.M. ve Grunig, J.E. (2005) "Halkla İlişkiler İşlevinin Örgütlenişi”, Grunig vd. (edt.), Halkla İlişkiler ve İletişim Yönetiminde Mükemmellik, İstanbul, Rota Yayın Dağıtım Tanıtım, 417439.

Dunning, J.H. ve Lundan, S.M. (2008) "Multinational Enterprises and the Global Economy", UK,Edward Elgar Publishing Limited,Second Edition.

Ehling, W.P. (2005) “Halkla İlişkiler Eğitimi ve Profesyonellik”, Grunig vd. (der.), Halkla İlişkiler ve İletişim Yönetiminde Mükemmellik, İstanbul, Rota Yayın Dağıtım Tanıtım, 463-488.

Emrich, C. (2007) “Interkulturelles Marketing-Management”, Wiesbaden, Deutscher UniversitätsVerlag.

Erdoğan, İ. (2006) “Teori ve Pratikte Halkla İlişkiler”, Ankara, Erk Yayınları.Fortune Global 500 (2012) "Global 500, 2011 Full List", http://money.cnn.com/magazines/fortune/fortune500/2012/snapshots/387.html?iid=splwinners . Erişim Tarihi: 28.12.2012

Fourboul, C.V. ve Bournois, F. (1999) "Strategic Communication with Employees in Large European Companies: A Typology”, European Management Journal, 03-04/, 204-217.

Freeman, E. (1984) “Strategic Management: A Stakeholder Approach”, Boston, Pitman.

Grunig, J.E., Grunig, L.A., Sriramesh, K., Huang, Y.H., ve Lyra, A. (1995) “Models of Public Relations in an International Setting", Journal of Public Relations Research, 7(3), 63-186. 
Grunig, J.E. ve Grunig, L.A. (2005) “Halkla İlişkiler ve İletişim Modelleri”, Grunig vd. (der.), Halkla İlişkiler ve İletişim Yönetiminde Mükemmellik, İstanbul, Rota Yayın Dağıtım Tanıtım, 307348.

Grunig, J.E. ve Repper, F.C. (2005) “Stratejik Yönetim. Kamular ve Gündemler”, Grunig vd. (der.), Halkla İlişkiler ve İletişim Yönetiminde Mükemmellik, İstanbul, Rota Yayın Dağıtım Tanıtım, $131-172$.

Grunig, J.E. (2005a) “İletişim, Halkla İlişkiler ve Etkin Örgütler: Kitaba Genel Bir Bakış”, Grunig vd. (der.), Halkla İlişkiler ve İletişim Yönetiminde Mükemmellik, İstanbul, Rota Yayın Dağıtım Tanitım, 11-39.

Grunig, L.A. (2005b) “Eylemcilik: Örgütlerin Etkinliğini Nasıl Sınırlıyor ve Mükemmel Halkla İlişkiler Departmanları Nasıl Karşılık Vermeli?’, Grunig vd. (der.), Halkla İlişkiler ve İletişim Yönetiminde Mükemmellik, İstanbul, Rota Yayın Dağıtım Tanıtım, 527-556.

Grunig, L.A., Grunig, J.E. ve Ehling, W.P. (2005) “Etkin Örgüt Nedir?”, Grunig vd. (der.), Halkla İlişkiler ve İletişim Yönetiminde Mükemmellik, İstanbul, Rota Yayın Dağıtım Tanıtım, 79104.

Heenan, D.A. ve Perlmutter, H.V. (1979) "Multinational Organization Development - A Systems Approach", Reading M.A, Addison Wesley Publication.

Holtzhausen, D.R. (2011) “The Need for a Postmodern Turn in Global Public Relations”, Nilanjana Bardhan ve C. Kay Weaver (ed.), Public Relations in Global Cultural Contexts, New York, Routledge, 140-166.

Keegan, W.J., Schlegelmilch, B.B. ve Stöttinger, B. (2002) “Globales MarketingManagement”, Oldenbourg, Wissenschaftsverlag GmbH.

Kent, M. ve Taylor, M. (2011) "How Intercultural Communication Theory Informs Public Relations Practice in Global Settings", Nilanjana Bardhan ve C. Kay Weaver (ed.), Public Relations in Global Cultural Contexts, New York, Routledge, 50-76.

Koparal, C. (2004) “Uluslararası İşletmelerde Stratejik Planlama”, İnan Özalp (ed.), Uluslararası İşletmecilik, Eskişehir, Anadolu Üniversitesi Yayını, No: 1576, 123-138.

Mutlu, E.C. (1999) “Uluslararası İşletmecilik”, İstanbul, Beta Basım Yayım Dağıtım A.Ş.

Ohmae, K. (1990) “The Borderless World”, New York, Collins.

Ohmae, K. (2006) “Ulus Devletin Sonu: Bölgesel Ekonomilerin Yükselişi”, Zülfü Dicleli (çev.), İstanbul, Türk Henkel Dergisi Yayınları.

Onkvisit, S. ve Shaw, J. (2004) "International Marketing. Analysis and Strategy”, New York, Routledge. 
Selmer, J. ve Leung, A.S.M. (2002) "Career Management Issues of Female Business Expatriates”, Career Development International, 7(6), 348-358.

Seyidoğlu, H. (1996) “Uluslararası İktisat. Teori Politika ve Uygulama”, İstanbul, Güzem Yayınları.

Sharpe, M. L. (1992) “The Impact of Social and Cultural Conditioning on Global Public Relations", Public Relations Review, 18, 103-107.

Sriramesh, K.; Kim, Y. ve Tabasabaki, M. (1999) "Public Relations in Three Asian Countries: An Analyis”, Journal of Public Relations Research, 11(4), 271-292.

Steyn, B. (1999) "CEO Expectations in Terms of PR Roles", Communicare, 19(1), 20-43.

Steyn, B. (2003) "From Strategy to Corporate Communication Strategy: A Conceptualisation", Journal of Communication Management, Vol. 8, No.2, 168-183.

Turney, M. (2009) “The Changing Name of Public Relations”, http://www.nku.edu/ turney/prclass/readings/pr_names.html. Erişim Tarihi: 24.12.2012

Ulaş, D. (2009) “Küreselleşme Sürecinde Dışa Açılma Stratejileri”, Ankara, Nobel Yayın Dağıtım. UNCTAD (2009) "World Investment Report 2009"

,http://www.unctad.org/templates/webflyer.asp?docid=11926\&intItemID=1465\&lang=1. Erişim Tarihi: 05.11.2011

Verčič, D., Grunig, J.E. ve Grunig, L.A. (1996) “Global and Specific Principles of Public Relations: Evidence from Slovenia", Culbertson ve Chen (eds.), International Public Relations: A Comparative Analysis, Mahwah, NJ, Lawrence Erlbaum Associates, 31-66.

Vercic, D. (2009) "Public Relations of Movers and Shakers: Transnational Corporations", Sriramesh, ve Vercic (eds.), The Global Public Relations Handbook: Theory, Research, and Practice, London, Lawrence Erlbaum Associates, Expanded and Revised Edition, 795-806.

Wakefield, R.I. (1996) "Interdisciplinary Theoretical Foundations for International Public Relations", Culbertson ve Chen (eds.), International Public Relations: A Comparative Analysis, Mahwah, NJ, Lawrence Erlbaum Associates, 17-30.

Wakefield, R.I. (2001) "Effective Public Relations in the Multinational Organization”, Heath (ed.), Handbook of Public Relations, Thousand Oaks, Sage Publications, 639-647.

Wakefield, R.I. (2009) “Uluslararası Halkla İlişkiler Teorisi, İnternet ve Aktivizm: Kişisel Bir Düşünce, F. Keskin ve P.Özdemir (der.), Halkla İlişkiler Üzerine, Ankara, Dipnot Yayınları, 89-115.

Wakefield, R.I. (2011) "World-Class" Public Relations One Decade Later: Does the Model Still Apply?, Public Relations Journal, Vol. 5, No. 3, 1-26. 
Warnaby, G. ve Moss, D. (2004) “The Role of Public Relations in Organisations”, Philip J. Kitchen (ed.), Public Relations Principles and Practice, London, International Thomson Business Press, 2-21.

White, J. ve Mazur, L. (1995). "Strategic Communications Management: Making Public Relations Work", England, Wokingham, Addison-Wesley.

Yıldırım Becerikli, S. ve Kılıç, N.P. (2012) “ Merkez ve Doğu Avrupa’da Halkla İlişkiler Uygulamaları: Romanya Örneği”, Ankara Üniversitesi Sosyal Bilimler Enstitüsü Dergisi, 3(2), 89-112.

Wright, D.K. (1995) "The Role of Corporate Public Relations Executives in the Future of Employee Communications, Public Relations Review, 21(3), 181-198.

Zaharna, R. S. (2001) “In-Awareness Approach to International Public Relations”, Public Relations Review, 27 (2001), 135-148. 